\title{
A study of platinum accumulation in radish (Raphanus sativus) and durum wheat (Triticum durum) plants
}

\section{Sofia Oke, Julie Kikkert, Luba Vasiluk, and Beverley Hale}

School of Environmental Sciences, Ontario Agricultural College, University of Guelph, Guelph, ON Canada. Faculty supervisor: Beverley Hale. For correspondence, please email: sofia.oke@gmail.com.

\section{Abstract}

The aim of this study was to investigate the accumulation of platinum (Pt) in $C_{3}$ plants. In this experiment, radish (Raphanus sativus) and durum wheat (Triticum durum) were chosen as test species and three uncontaminated soils from Simcoe, Elora, and Kettleby, Ontario were chosen to represent a range of soil characteristics. Soils were amended with 0 to

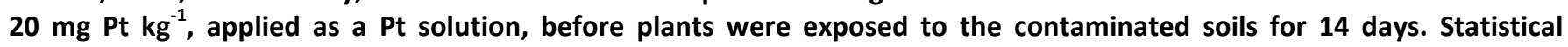
analyses using a Linear Model Procedure and a Student-Newman Keuls Test at $\alpha=0.05$ found a significant different between Pt accumulation and plant type, tissue type, and soil type. Overall, root tissue in all soil and plant types accumulated approximately eight times more Pt than the corresponding shoot tissue $(p<0.0001)$. Soil type also yielded a significant effect on the accumulation of $\mathrm{Pt}$ in both durum wheat and radish plants. Simcoe, a sandy soil with a low cation exchange capacity (CEC), had the highest levels of Pt accumulation. Kettleby soil, with the highest CEC and soil organic matter (SOM) yielded the lowest levels of Pt accumulation across all tissue and plant types. Finally, plant type was also statistically significant in Pt accumulation. Radish plants (dicotyledonous) accumulated higher amounts of Pt in comparison to wheat plants (monocotyledonous). It appears that Pt accumulation in plants is moderated by soil physiochemical properties that limit its bioavailability in soil. Limiting Pt in plants should include an assessment of soil bioavailability.

Keywords: platinum (accumulation and bioavailability of); (Raphanus sativus) plants; durum wheat (Triticum durum) plants; soil, plant, and tissue type (effects of)

\section{Introduction}

Platinum (Pt) is a silvery-white and chemically inert transition metal (Banfield, 2002). As a noble metal, it carries oxidation states of +2 and +4 ; however, it will not oxidize in air and is resistant to most acids (Paraskevas, Tsopelas, \& Ochsenkühn-Petropoulou, 2011). If dissolved in acidic solutions, Pt favours the formation of complex ions, which can accumulate in plants. These complexes are quite bioavailable and highly toxic; thus, they are a concern for secondary poisoning from plant accumulation (Hooda, Miller, \& Edwards, 2007). There is little known on the influence of physical and chemical properties of $\mathrm{Pt}$ that allow for its uptake into terrestrial environments upon release from natural and anthropogenic sources.

In the environment, the main source of Pt pollution in soil and roadside dust is from its function in car catalytic converters (Paraskevas et al., 2011). Platinum is used as an electrode in catalytic converters to reduce the emissions of ozone-depleting substances such as carbon monoxide and nitrogen oxides (Paraskevas et al., 2011). Platinum catalyzes the oxidation of carbon monoxide to carbon dioxide and converts nitric oxide to nitrogen and water (Banfield, 2002). Although Pt is mean to serve a beneficial role, the flow of hot exhaust gases through catalytic converters causes the gradual abrasion of the electrode surface, which causes $\mathrm{Pt}$ emissions (Paraskevas et al., 2011). On average, a single catalytic converter releases $200 \mathrm{ng} \mathrm{Pt} \mathrm{km}{ }^{-1}$ (Zimmerman \& Sures, 2004). A fraction of this platinum is released in its soluble form but the exact amount is unknown (Hooda et al., 2007). Platinum emission is minimal when a single car is considered but any effect is multiplied many times over considering the hundreds of millions of automobiles on the road each day.

The purpose of this study was to investigate the accumulation of Pt in plant root and shoot tissue. For this experiment, three soil types were used to understand how soil characteristics influenced the availability of Pt to the test species. Soil cation exchange capacity (CEC), $\mathrm{pH}$ and soil organic matter (SOM) generally influence the phytoavailability of trace metals in soils by regulating the 
proportion of dissolved metal in its free ionic state (Antunes et al., 2006). It is important to note that the free ion concentration is not always sufficient to predict neither metal accumulation in plants nor toxicity (Antunes et al., 2006). Ion competition for binding to the biotic ligand (in this case, the root), should also ideally be considered but were not explored for the purposes of this experiment.

Wei and Morrison (1994) suggest that Pt is readily bound to the organic matter component of soils. The transformation of Pt from an inorganic ion to an organically bound species in soil organic matter (SOM) is hypothesized to be positively associated with its ability to accumulate in plants. Large amounts of SOM in soil result in increased immobilization of free $\mathrm{Pt}$ in soil and thus a reduced availability for plant uptake (Wei \& Morrison, 1994). Thus, it is hypothesized that Pt will be better accumulated in soils with a low SOM.

There are few studies published on the uptake of Pt by plants, particularly $\mathrm{C}_{3}$ plants, which are plants in which carbon fixation and photosynthesis occur in the mesophyll cells (Earlham, 2002). In this experiment, radish (Raphanus sativus) and durum wheat (Triticum durum) were chosen as test species. Radish and durum wheat are important foods for human consumption and thus provide insight into the possible risks of consuming Pt contaminated plants (Earlham College, 2002). Additionally, radish is dicotyledonous and durum wheat is monocotyledonous, allowing for a physiological comparison of $\mathrm{Pt}$ accumulation. Since monocots and dicots vary in their water use efficiency (WUE), it was an objective of this analysis to determine if there is a relationship between WUE and Pt distribution in plant tissue.

\section{Materials \& Methods}

A standard protocol developed by Environment Canada (EC) (EPS 1/RM/45) was used in this experiment (Environment Canada, 2007). A brief overview of the protocol is outlined in the following passages.

\section{Harvesting procedure}

Three uncontaminated arable soils from Ontario that represented a range of soil characteristics were chosen and collected from research stations affiliated with the University of Guelph: Simcoe Research Station (Simcoe, ON), Elora Research Station (Elora, ON), and the Muck Crops Research Station (Kettleby, ON) (Table 1). All soils were dried, ground, and sifted to less than two $\mathrm{mm}$ in size.

Dried soils were placed into 15 acid washed, plastic containers and rehydrated to $70 \%$ water holding capacity (WHC) with ultrapure water. Soils were spiked with 0, 0.5, 1 , 10 , or $20 \mathrm{mg} \mathrm{Pt} \mathrm{kg}{ }^{-1}$ by diluting a known Pt standard (1000 $\mathrm{mg} \mathrm{L}^{-1}$ in a $10 \% \mathrm{HCl}$ matrix from Fisher Scientific) in ultrapure water and adding it to the soil using spray bottles. Soils were then well mixed by hand, covered, and allowed to age for 12 days; the soils were not leached. Following the aging period, soil $\mathrm{pH}$ was measured with $0.1 \mathrm{M} \mathrm{CaCl} 2$ (Hendershot, Lalande, \& Duquette, 1993).

Table 1. Background soil properties for the three soils used in the experiments.

\begin{tabular}{|llll|} 
& $\begin{array}{l}\text { Muck } \\
\text { Research } \\
\text { Station }\end{array}$ & $\begin{array}{l}\text { Simcoe } \\
\text { Research } \\
\text { Station }\end{array}$ & $\begin{array}{l}\text { Elora } \\
\text { Research } \\
\text { Station }\end{array}$ \\
\hline CEC $\left(\mathbf{c m o l}^{+} \mathbf{~ k g}^{-1}\right)$ & $47.54 \pm 0.28$ & $0.84 \pm 0.00$ & $6.72 \pm 0.04$ \\
\hline $\begin{array}{l}\text { Bulk Density } \\
\left(\mathbf{g ~ c m}^{-3}\right)\end{array}$ & 0.95 & 1.43 & 1.70 \\
\hline Soil pH & $6.6 \pm 0.03$ & $5.4 \pm 0.03$ & $7.6 \pm 0.00$ \\
\hline Soil Texture & organic & sand & loam \\
\hline SOM & $73.8 \pm 1.3$ & $0.8 \pm 0.03$ & $4.0 \pm 0.03$ \\
\hline
\end{tabular}

After the 12-day aging period, equal masses of soil were weighed out into acid-washed, clear polypropylene $1 \mathrm{~L}$ containers. In each container, five seeds of either radish or durum wheat were planted before the pots were placed into a growth chamber. The growth chamber was programmed to a photoperiod of $16 \mathrm{~h} / 8 \mathrm{~h}$ day and night cycle. The temperature remained constant at $24^{\circ} \mathrm{C}$ with the relative humidity at $60 \%$ with exposure to full spectrum light at a fluence rate at 300 lux. Container lids remained in place until the seventh day before being removed. Plants were watered as needed. At the end of 14 days, plants were removed from soil and separated into root and shoot tissue. Roots and shoots were placed into paper envelopes and oven-dried at $60^{\circ} \mathrm{C}$ for 24 to 48 hours. Dry weights of root and shoot tissues were recorded.

\section{Chemical analysis}

To determine Pt accumulation in plants, dry root or shoot tissue was weighed into Teflon digestion vessels before 10 $\mathrm{mL}$ of trace metal grade nitric acid $\left(\mathrm{HNO}_{3}\right)$ was added (Topper \& Kotuby-Amacher, 1990). Tissue was predigested for about 6 hours before being placed in an oven overnight at $110^{\circ} \mathrm{C}$; samples were then filtered and diluted to $20 \%$ nitric acid with ultrapure water. Platinum in soil and plant samples was analysed with a Zeeman-background correction Varian ${ }^{\circledR} 880$ Graphite Furnace Atomic Adsorption Spectrometer (GFAAS) with a detection limit of $3 \mu \mathrm{g} \mathrm{L}^{-1}$. The GFAAS was run at an atomization temperature of $2700^{\circ} \mathrm{C}$, an ashing temperature of $1100^{\circ} \mathrm{C}$, and a cleaning temperature of $2850^{\circ} \mathrm{C}$, applied for 3 seconds. The graphite tube was changed every 150 firings and the tube was cleaned every five to six samples.

Statistical software (SAS version 9.1) was used to test for significance using the General Linear Model Procedure (PROC GLM). For the statistical analysis Student-NewmanKeuls (SNK) and Tukey Honestly Significant Tests were performed. Sigma Plot (Version 11.3) was used to create all figures seen in this document. 


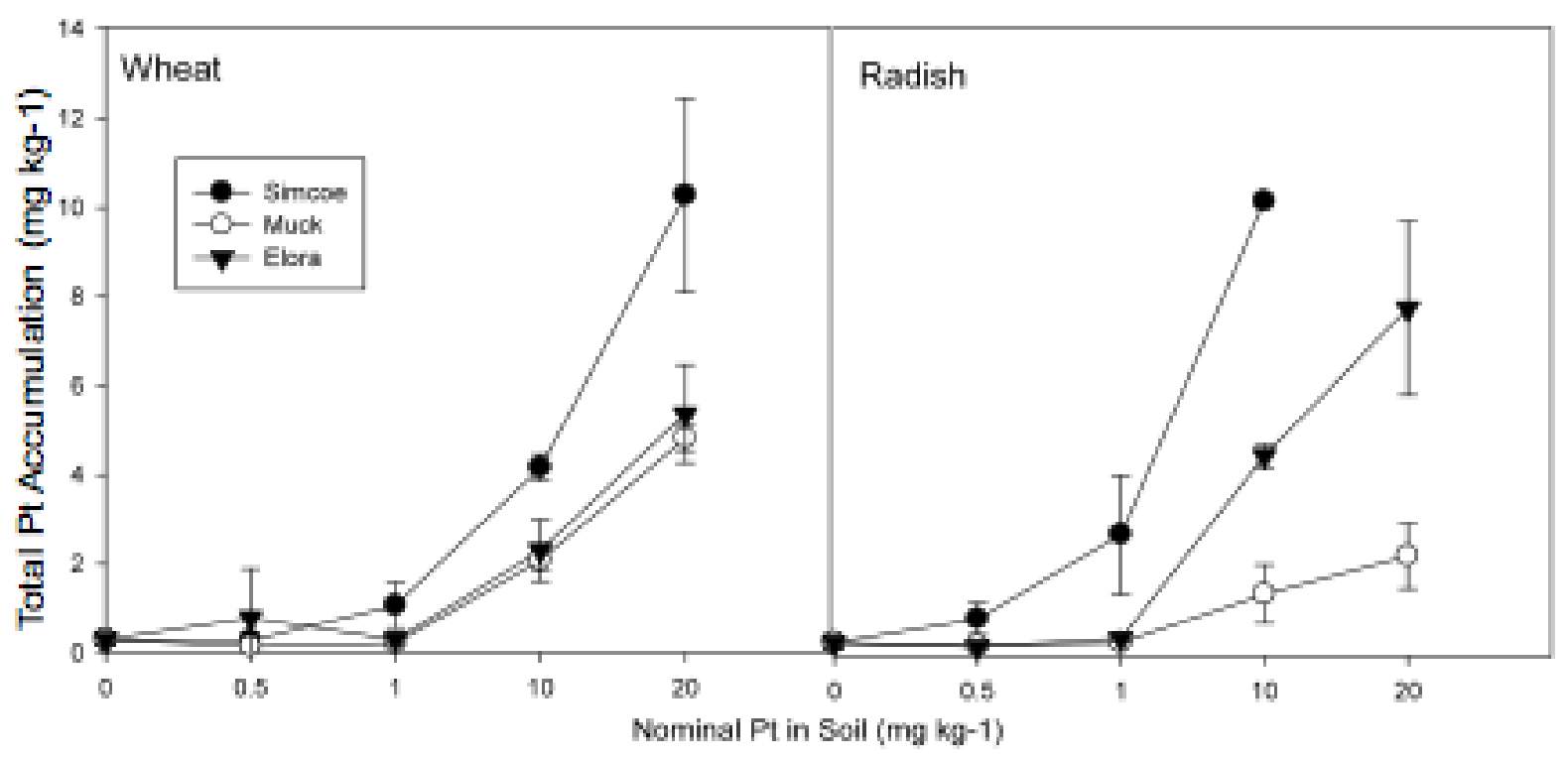

Figure 1. Scatter plots comparing the total plant Pt accumulation $\left(\mathrm{mg} \mathrm{kg}^{-1}\right)$ for durum wheat and radish plants across all three soil regions: Simcoe, Elora, and Kettleby, Ontario. The left graph represents Pt accumulation in durum wheat tissue while the right graph shows Pt accumulation in radish tissue.

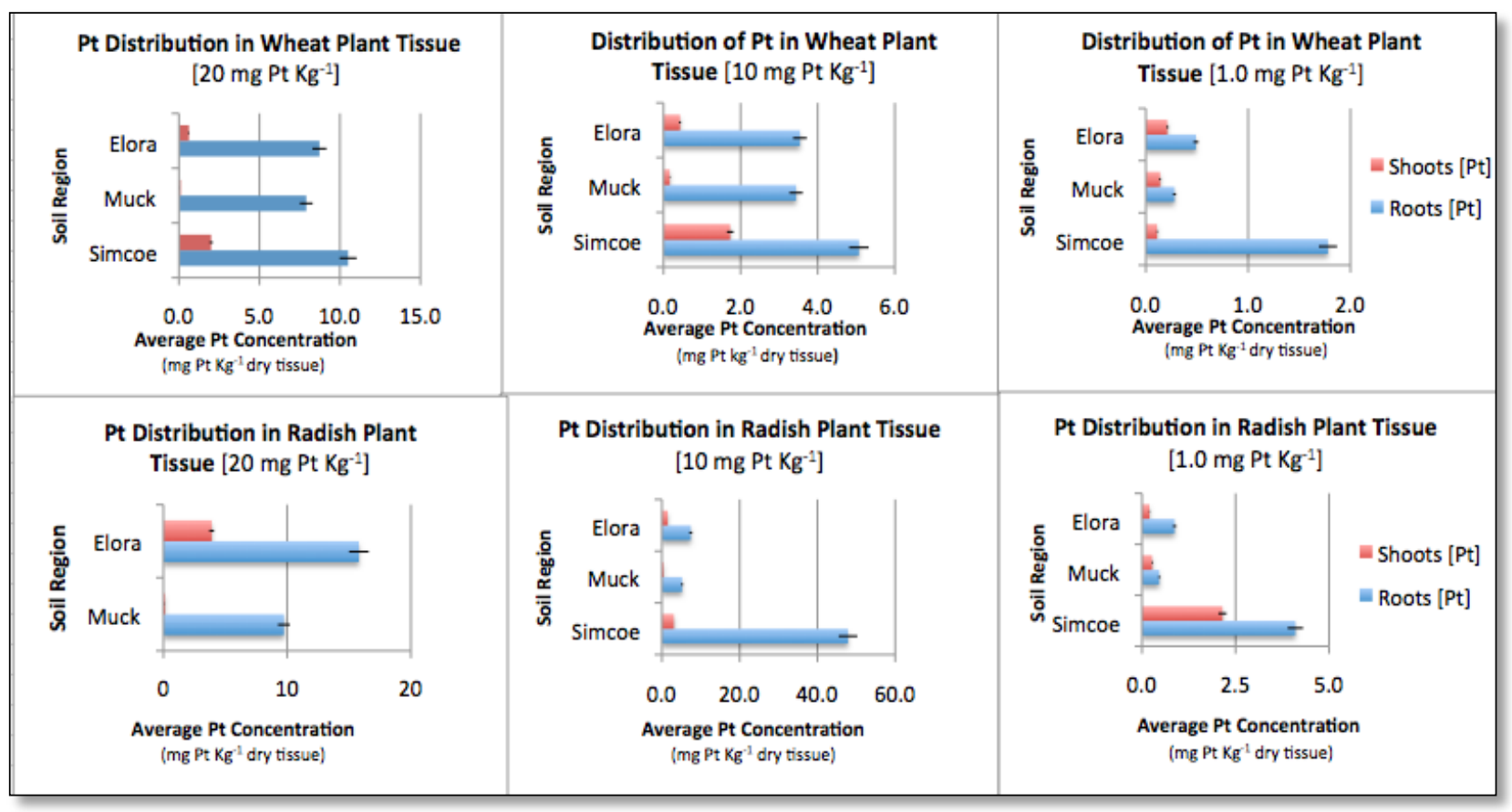

Figure 2. Bar graphs comparing average Pt concentration (mg Pt kg-1 dry tissue) to tissue type. The top panel represents Pt concentrations in durum wheat plants, while the bottom panel represents Pt concentration in radish plants. 


\section{Results \& Discussion}

Soil region had a significant effect on Pt accumulation. All three soil regions had statistically different $\mathrm{Pt}$ accumulations from one another when compared within plant or tissue type amended with 1,10 and $20 \mathrm{mg} \mathrm{Pt} \mathrm{kg}^{-1}$ soil. There was no significant difference in $\mathrm{Pt}$ accumulation between plants spiked with $0.5 \mathrm{mg} \mathrm{Pt} \mathrm{kg}$ and those left untreated. There were higher root tissue Pt concentrations in those grown in the Simcoe soil compared to the Elora or Kettleby soils. See Figure 1 for side-by-side comparisons of total $\mathrm{Pt}$ accumulation $\left(\mathrm{mg} \mathrm{kg}^{-1}\right)$ for each of the three soil regions. Table 1 summarizes the background characteristics of each soil region tested in this experiment.

With respect to the effect of soil characteristics on $\mathrm{Pt}$ accumulation, CEC and SOM could both have contributed to the results obtained in this experiment. The Simcoe soil had the lowest CEC of the three soils and thus was initially hypothesized to have the highest free ionic Pt available for uptake. Simcoe soils also had the lowest SOM content, allowing less Pt to be organically bound and immobilized within the soil. Both CEC and SOM can explain the high accumulation of $\mathrm{Pt}$ in the Simcoe soil relative to the other soils tested.

Among all plant and soil types, root tissue accumulated more $\mathrm{Pt}$ than the shoot tissue. Figure 2 illustrates the concentration of Pt in each plant root and shoot tissue based on its specific soil amendment, plant type and soil region. Across all soil types, roots accumulated eight times $(p<0.0001)$ more $\mathrm{Pt}$ than shoots. It appears that $\mathrm{Pt}$ sequestration and complexation mechanisms are in the roots of radish and durum wheat plants. These mechanisms should be considered as the location for reduced $\mathrm{Pt}$ translocation via xylem to the shoots.

In general, mechanisms of metal uptake and translocation from root to shoot tissue are dependent on the specific metal ion as well as the type of plant being studied (Gagnon, 2006). Some ions require highly specific binding domains in their transmembrane transporters, while others require less specific mechanisms. Similarly, a significant fraction of the metal ion may be absorbed by the extracellular carboxyl groups within the root cell wall, limiting translocation. Other metals may be heavily sequestered and complexed in vacuoles thus limiting available uptake into the shoots (Lasat, Fuhrmann, Ebbs, Cornish, \& Kochain, 1998). The mechanisms that are used by plants to mobilize or immobilize Pt have yet to be determined; however, there is evidence from this experiment that suggests that either one or both of these mechanisms are involved in reducing the available $\mathrm{Pt}$ for translocation to shoot tissue.

Compared to wheat, radish plants accumulated $46 \%$ more $\mathrm{Pt}$ when accumulation is averaged across all soil $\mathrm{Pt}$ concentrations. Expressed on a whole plant basis, radish accumulated $2.70 \mathrm{mg} \mathrm{Pt} \mathrm{kg}{ }^{-1} \mathrm{DW}$ compared to $1.85 \mathrm{mg} \mathrm{Pt}$ kg-1 DW in wheat plants. Furthermore, all of the radish plants spiked with $20 \mathrm{mg} \mathrm{kg}^{-1}$ of $\mathrm{Pt}$ died during the experimental period while at the same concentration, all of the wheat plants survived. It is hypothesized that the difference in Pt accumulation between plant species is due to differences in vascular patterns (Khan, 2005). Radish plants have branched veins whereas wheat plants have a parallel vein structure. The branched veins of radish plants are more abundant than the parallel veins of wheat plants and may be responsible for increased water and dissolved solute accumulation (Khan, 2005). Increasing the uptake of soluble $\mathrm{Pt}$ ions from the soils would increase Pt accumulation in radish compared to wheat.

\section{Conclusions}

Overall, regardless of soil and plant type, root tissue accumulated eight times more Pt than the corresponding shoot tissue. Soil type had a significant effect on the accumulation of $\mathrm{Pt}$ in durum wheat and radish plants. Simcoe soil, a sandy soil with a low CEC, had the greatest Pt accumulation. Muck soil, with the highest CEC and SOM, had the least $\mathrm{Pt}$ accumulation across all tissue and plant species. Amongst $\mathrm{C}_{3}$ plants, there was a significant difference between $\mathrm{Pt}$ accumulation in radish and durum wheat plants. It is suggested that the vascular features involved with WUE may influence Pt accumulation. It appears that $\mathrm{Pt}$ accumulation in plants is moderated by the soil physiochemical properties that limit its bioavailability in soil. Limiting Pt in plants should include an assessment of soil bioavailability.

Further research is recommended to determine the specific mechanisms of sequestration and complexation used by plants when exposed to $\mathrm{Pt}$ in soil. In the future, it would be beneficial to perform accumulation analyses using the extractable concentration of $\mathrm{Pt}$ in the soil as opposed to the nominal spike concentration used in this experiment. With the use of the extractable concentration of $\mathrm{Pt}$ in the soil, a mass-balance analysis could be performed to determine the Pt distribution from the available soil fraction to the root and the shoot. Finally, repeated trials using larger and more diverse collection samples would be recommended for future investigations of this nature. While this study did yield many significant differences, it is important that this experiment be repeated to ensure reproducibility of results. 


\section{Acknowledgements}

It was a great pleasure to assist with this analysis of $\mathrm{Pt}$ accumulation as part of a much larger Environment Canada research study. The principal investigator (S.O.) would sincerely like to thank Luba Vasiluk and Julie Kikkert for taking the time to teach lab techniques and the operation of lab equipment. Both of their genuine desires to help whenever help was needed were wonderful and really appreciated. Thanks is also given to Taylor Wallace and Daniel Clancy for their work performing the harvesting proceedure and design of this experiment. Peter Smith was also instrumental in teaching about the GFAAS and troubleshooting issues that arose. Finally, thank you to Dr. Beverely Hale for her guidance and support in directing this research.

\section{References}

Antunes, P.M., Berkelaar, E.J., Boyle, D., Hale, B.A., Hendershot, W., \& Voigt, A. The biotic ligand model for plants and metals: Technical challenges for field application. Environmental Toxicology and Chemistry, 25, 875-882.

Banfield, J., \& Cook-Wallace, H. (2002). Jems and precious stones. Retrieved on January 25, 2014 from: http://nature.berkeley.edu/classes/eps2/wisc/glossary2.html

Earlham College. (2002). C3, C4, and CAM plants. Retrieved on January 25, 2013 from: http://legacy.earlham.edu/ vandeel/notes.htm

Environment Canada. (2007). Biological Test Method. Test for measuring emergence and growth of terrestrial plants exposed to contaminants in soil EPS1/RM/45.

Gagnon, Z.E., Newkirk, C.A., \& Hicks, S.T. (2006). Impact of platinum group metals on the environment: A toxicological, genotoxic, and analytical chemistry study. Journal of Environmental Science and Health Part A, 41, 397-414.

Hendershot, W.H., Lalonde, H., \& Duquette, M. (1993). Ion exchange and exchangeable cations. In M.R. Carter (Ed.), Soil Sampling and Methods of Analysis. 167-176. Boca Raton, Florida: Lewis Publishers.

Hooda, P.S., Miller, A.E., \& Edwards, A.C. (2007). The distribution of automobile catalysts-cast platinum, palladium and rhodium in soils adjacent to roads and their uptake by grass. Science of the Total Environment, 384, 384-392.
Khan, A.G. (2005). Role of soil microbes in the rhizospheres of plants growing on trace metal contaminated soils in phytoremediation. Journal of Trace Elements in Medicine and Biology, 18, 335-364.

Lasat, M., Fuhrmann, M., Ebbs, S., Cornish, J., \& Kochain, L. (1998). Phytoremediation of a radiocesium-contaminated soil: Evaluation of a cesium-137 bioaccumulation in the shorts of three plant species. Journal of Environmental Quality, 27, 165-169.

Paraskevas, M., Tsopelas, F., \& Ochsenkühn-Petropoulou, M. (2012). Determination of Pt and Pd in particles emitted from automobile exhaust catalysts using ion-exchange matrix separation and volumetric detection. Microchimica Acta, $176,235-242$.

Topper, K., \& Kotuby-Amacher, J. (1990). Evaluation of a closed vessel acid digestion method for plant analysis using inductively coupled plasma spectroscopy. Communications in Soil Science and Plant Analysis, 21, 1437-1455.

Wei, C., \& Morrison, G.M. (1994). Platinum in road dusts and urban river sediments. Science of the Total Environment, 146/147, 169-174.

Zimmerman, S.O., \& Sures, B.E. (2004). Significance of platinum group metals emitted from automobile exhaust gas converters for the biosphere. Environmental Science and Pollution Research, 11, 194-199.

\section{Additional References}

Babula, P.A., Vojtech, A.R., Opatrilova, R.A., Zehnalek, J.O., Ladislav, H.A., \& Kizek, R.I. (2008). Uncommon heavy metals, metalloids, and their plant toxicity: A review. Environmental Chemistry, 6, 189-213.

Chwastowska, J., \& Skwara, W.E. (2004). Determination of platinum and palladium in environmental samples by graphite furnace atomic absorption spectroscopy after separation on dithizone sorbent. Institute of Nuclear Chemistry and Technology, 1, 224-229.

Ravindra, K.H., Bencs, L.S., \& Van Grieken, R.E. (2004). Platinum group elements in the environment and their health risk. The Science of the Total Environment, 318, 1-43.

Sutherland, R.A. (2003). A first look at platinum in roaddeposited sediments and roadside soils, Honolulu, Oahu, Hawaii. Archives of Environmental Contamination and Toxicology, 44, 430-436. 